\title{
Ljubiša Bojić
}

Institute for Philosophy and Social Theory,

University of Belgrade

ljubisa.bojic@instifdt.bg.ac.rs

Maja Zarić

Advisor at Ministry of Culture, Republic of Serbia

maja.zaric@kultura.gov.rs

Simona Žikić

Faculty of Media and Communications, Singidunum University Institute for Philosophy and Social Theory,

University of Belgrade simona.zikic@fmk.edu.rs

\section{Worrying Impact of Artificial Intelligence and Big Data Through the Prism of Recommender Systems}

\begin{abstract}
Transfer from social to semantic web brought us to an era of algorithmic society, placing issues such as privacy, big data and AI in the spotlight. although neutral by their nature, the power of big data algorithms to impact societies became major concern outcoming with fines issued to Facebook in the US. These events were initiated by alleged breaches of data privacy connected to recommender system technology, which can provide individualized content to internet users. This paper seeks to explain recommender systems, while elaborating on their social effects, to conclude that their overall impacts might be increase in retail sales, democratization of advertising, increase in internet addictions, social polarization (echo chamber issue), and improvement of political communication. Also, more research should be deployed into low intensity addictions, as potential outcome of recommender systems, and it should be explored how they affect political participation and democracy.
\end{abstract}

Key words: recommender systems, ai, big data, internet addiction, echo chamber

Introduction

Big changes in societies around the world are caused by the development of internet. The new era of big data is characterized by "high volume, velocity, variety, exhaustivity, resolution, indexicality, relationality and flexibility" (Kitchin 
2013, 262). Technology companies have been taking places on the list of most valuable companies in the world (Statista 2019), followed by increases in internet use, across the globe, from $0.4 \%$ in 1995 to $59.6 \%$ in 2020 (Internetworldstats 2020). "The speed of development in big data and associated phenomena, such as social media, has surpassed the capacity of the average consumer to understand his or her actions and their knock-on effects", writes Zwitter (2014, 1). Businesses have been moving and extending online during that period, while new internet services have been developing. Instant connectivity between people increased with appearance of social media, taking leadership place in these developments (Sutikno et al. 2016). Era of social web 2.0 started in early 2000 s to be called web 2.0, followed by web 3.0 or the semantic web, a period in the development of internet in which we live in (Patel and Jain 2019). This era relies on access to user information by organizations to conduct either AI or not-AI algorithmic analysis, finally outcoming with recommend ads and content. Econ (2016) calls big data the new oil, because it is needed by algorithms and AI to function and run the algorithmic society. However, advances both in hardware and software give corporations an opportunity to handle big data, providing their users instant recommendations, but without transparency and firm regulations for data analyses.

This topic gained its international importance after US elections and Brexit vote, which had unexpected outcomes, after targeted political marketing, which included personality detection to deliver promotional content of different emotional intensity (Howard et al. 2019). Donald Tramp became president of the USA on one side, and Great Britain decided opt out from the European Union. Again, although algorithms are neutral by their nature, these events made both politicians and common citizens believe in power of big data to change governments by in depth analysis of the electorate. "Big data and predictive analytics all of a sudden became very concrete for the public - and people came to realize that personal information is in fact a commodity that is sold and traded among information empires and data brokers", writes Mai $(2016,193)$. Fear of social power holders of being out of control concerning political marketing and its outcomes may have been the leading triggers for imposing new regulations about protection of privacy. On the other hand, the United States fined Facebook for data breaches. Facebook's CEO Mark Zuckerberg promised he would improve privacy of its users, but without a clear plan how his company would do that (Hern and Pegg 2018).

Kitchin and McArdle (2016) explore what makes constitutes big data. Laney (2001) writes that the concept of big data is defined by: volume, consisting of massive quantities of data, velocity, created in real time and variety. The new concept of algorithmic society is explained by Balkin (2017), who sees big technology corporations taking place between governments and society members. $\mathrm{He}$ calls it a pluralist model of a nation state, in which individual is controlled 
by both corporations, operating in multiple jurisdictions and governments. Balkin envisions struggle for power between these corporate multinational entities and governments. Algorithms have become the main mediator through which power is enacted in our society, claim Schuilenburg and Peeters (2021) and add, "Governments are increasingly turning towards algorithms to predict criminality, deliver public services, allocate resources, and calculate recidivism rates. Mind-boggling amounts of data regarding our daily actions are analysed to make decisions that manage, control, and nudge our behaviour in everyday life".

Milano, Taddeo and Floridi (2020) provide definition of recommender systems in regard to e-commerce as the products offered in the catalogue versus ones that ultimately result in purchases. Other definition configured by Floridi (2008) speaks of good news recommendation, as the one that is clicked on and thus relevant to the user. Another view comes from Abdollahpouri, Burke, and Mobasher (2017) defining recommender system as multi-stakeholder environments where multiple parties can derive different utilities from recommendations. More technical definition explains recommender system as decision making strategy for users under complex information environments (Rashid 2002). Finally, the one by Resnick and Varian (1997) explains recommender system as a means of assisting and augmenting the social process of using recommendations of others to make choices when there is no sufficient personal knowledge or experience of the alternatives. Going into rather different direction, we shall provide our working definition of recommender system, in context of society. We consider recommender system as a process in which user data is analyzed to choose between certain options for each of the users, then show selected options back to them individually, to achieve some or all of the following goals: to get attention, extend usage of online content, assist users get content they are interested in, spark thinking and discussion, change opinions and initiate actions, including purchasing and voting behavior.

Data processing can be done in straightforward algorithmic way, but also involving artificial intelligence technologies, out of which machine learning may be the most common one applied in recommender systems (Helberger, Karppinen and D'Acunto 2016). This kind of algorithm learns from great amount of data, then makes predictions and recommendations. The main issue around AI is the black box issue, because it is almost impossible to understand why the algorithm made some decision, as being based on combination of many small correlations. However, it is possible to measure if an AI algorithm is effective. The capabilities of AI technologies are indicated by many research studies, such the one by Kosinski, Stillwell and Graepel (2013) which found AI can accurately predict different personal attributes of social media users, such as sex orientation, ethnicity, religious and political views, personality traits, intelligence, happiness, use of addictive substances, parental separation, age, and gender. 
Other paper indicates AI technology can be accurate at detecting sexual orientation and personality traits from facial images (Wang and Kosinski 2018). These are just examples of how widespread use of AI technologies can be spanning from implementation in recommender systems to integration into numerous other fields and processes.

Technology companies have the highest market values compared to companies from all other sectors. Out of top 10 most expensive in the world, 7 are technology corporations including Microsoft, Apple, Amazon, Alphabet, Facebook, Alibaba and Tencent (Statista 2020). On the other hand, when it comes to profitability, 4 of them are in top 10 most profitable corporations, competing with those in oil, financial and automobile manufacturing sectors. One of the main businesses of all noted companies concerns online services. These rankings indicate importance and influence held by technology companies that handle user data. The main influence of recommender systems, and thus the companies which handle them, may be in their overall social effects. That's why recommender systems transcend power of profitability, or market value of companies that control them. In other words, they may impact economic, political and other aspects of societies around the world. "The basic idea is that as big data becomes mainstream and businesses and state agencies apply predictive analysis to generate new information and knowledge about customers and citizens, a shift in focus from data collection to data processing is needed" (Mai 2016, 192).

In their effort to analyze ethical challenges of recommender systems Milano, Taddeo and Floridi (2020) note the gap in literature with providers of recommender systems and society at large, mainly omitted from consideration, while main focus is directed towards receivers of the recommendations.

Based on presented potentials of AI technologies and impact concerns that have been arising, the following question arises: what are potential social effects of recommender systems? The article explains recommender systems in more detail and reviews empirical evidences presented in around 50 research inquiries on social effects of recommender systems.

\section{How Recommender Systems Work}

Recommender systems make personalized recommendations to users of any online application. Recommendations may be ads, trending content, posts, friends or comments. With many potential purposes, recommender systems are implemented as integral parts of different online services including social media, messaging apps, e-commerce websites, email, search and various related apps. Main segment of any recommender system is an algorithm, which may be 
set of simple straightforward rules dictating how the content is being processed, or it can involve artificial intelligence. The following are three most common everyday uses of recommender systems: advertising platforms recommend ads to internet user; trending content is proposed to users of social media and posts of friends are selected to be shown to social media users. Main purpose of recommender systems is keeping users engaged by presenting personalized content to them. The way this is done is by harvesting data from users, analyzing them and then delivering content based on outputs of analysis (Aggarwal 2016).

\section{Ads}

The most common recommender system is ads recommendations. Main purpose for this kind of system is delivering ads that will get as much views, clicks and purchases as possible. "The effectiveness of advertisement distribution highly relies on well understanding the preference information of the targeted users" (Li and Shiu 2012, 9).

As mentioned before, all recommender systems work with user data in order to make recommendations in the first place. In order to get the data, Terms and Conditions of most online apps must define provision of services in return for data from the user. For example, Google provides email, search and many other services free of charge, but it gets user data in return. These can be used by the company, with or without the possibility to forward the data to third parties.

The best way to understand complexity of recommender systems is to focus on ads business, as its algorithms take into account multiple parameters included into its calculations, such as keywords (interests), location and other possible demographics to deliver personalized ads. This kind of marketing analysis is called psychometrics.

\section{Social Media}

On the other hand, trending content on the trending page is part of social media which provides content based on combination of personal interests and popular content at that particular moment. Example of this may be when social media user looks for a new interesting content to consume, while getting options from the profiles that he or she does not necessarily follow. This recommender system will show similar content or "you may be interested in" content, that is consumed by similar users (Ricci, Rokach and Shapira 2010).

Different kind of recommender system is the one used by social media that shows posts of friends or connections. In some cases, because of high number of connected profiles, all posts cannot be shown to the user and then selection has 
to come into play. Usually, this selection is based on most interactions, so the user gets content from people that he or she interacts with the most.

One of the most common recommender systems experienced by social media user is "friends you may know" feature. These are profiles proposed to the user by social media. The criteria used to get these recommendations are level closeness of the profile that gets recommendation to the profile that is recommended. That means they should have common friends. The other criteria can be physical distance, as well.

Although there are many different recommender systems all over the internet, there are two main principles for choosing the content that would be recommended to users. The first principle is, if a user has consumed lots of content similar to the other user, then the two users are considered similar, so the same content will be shared between them. The second principle is proposing similar content, by looking at what other content is consumed by those that saw the content that is consumed by the user that gets the recommendation. This is explained by Konow et al. (2010) and illustrated on Figure 1.0.

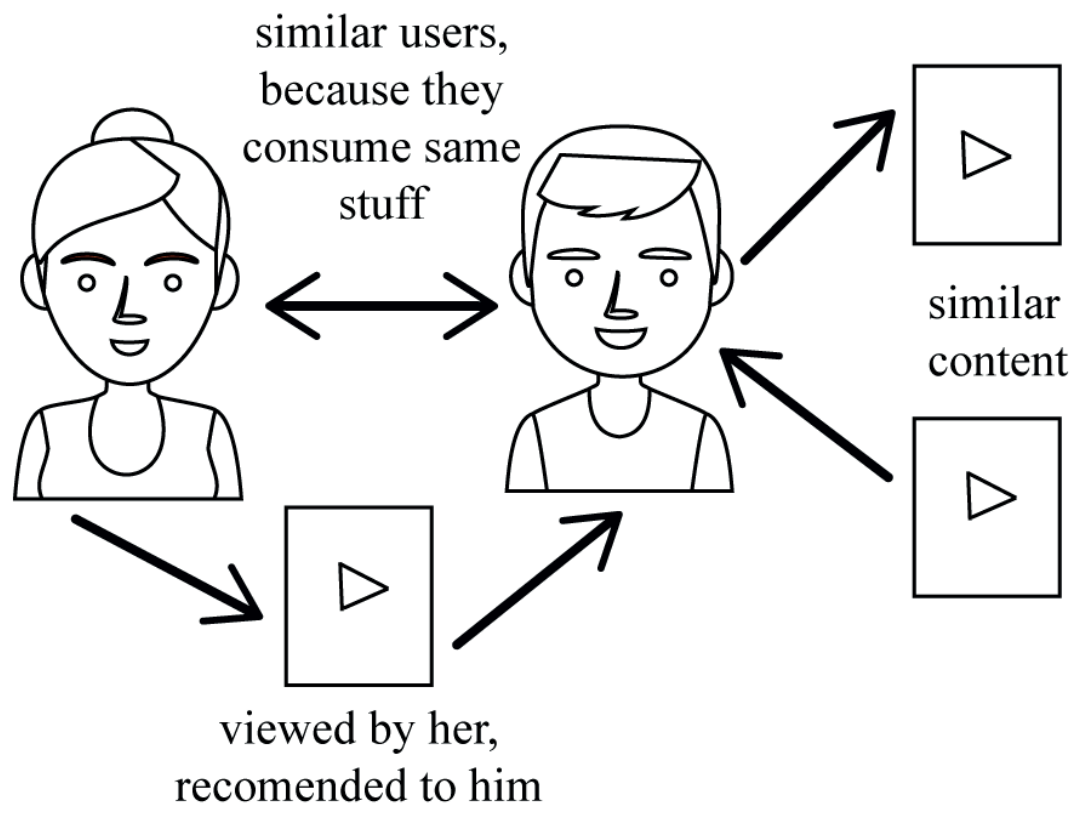

Figure 1.0. Illustrating two main principles that recommender system may be based on: similar content and similar users. Example for the first principle is that other content consumed by people viewing or reading the same stuff, as the user, is offered to that user. Example for the second principle is: content with same words in title or same keywords is suggested, as next to be consumed. 


\section{Applications}

The most prominent social media such as Facebook, Twitter, Instagram, YouTube and Tik Talk use various recommender systems. Main business model in these cases is keeping users engaged on social media platform, while gathering data from them to deliver personalized ads. Messaging apps include Messenger, Viber, WhatsApp, WeChat etc. Main purpose of recommender systems within messaging aps are advertising and motivating users to send new messages. For example, we can see ads in Viber after a successful call, within Communities, in the sticker market or on the chats list. Differently, on WhatsApp, ads are integrated in WhatsApp statuses that show pictures, videos, texts and other multimedia that users share with their contacts. Facebook Messenger offers interest-based ads used to initiate text conversations with businesses. Finally, WeChat displays promotional messages on user timeline, or at the bottom of WeChat articles (Sutikno et al. 2016). The most important function of recommender systems for music and video services such as YouTube, NetFlix and Spotify is recommending content. This keeps users on the spot, extending minutes of their use, as it keeps suggesting them content which is interesting to consume. Finally, online shopping platforms that include Amazon and Alibaba use product recommenders to offer items that have the greatest probability to get interest and ultimately get purchased by the users. Google, Yahoo, Bing, Hotmail and others provide various services such as search and email. They use variety of recommender systems to keep their users engaged and offer them the most appealing ads. On the other hand, indirect data handlers are companies that collect data for ads targeting. They handle data provided by consent from numerous websites visited everyday by billions of people. These data are analyzed in a way that it provides companies and advertising agencies an opportunity to show the ads to the people that will most probably be interested in them. Most people avoid reading Cookies Consent, while they give permission for their data to be further distributed or sold. Finally, developers of apps are indirect data handlers, that may use data for recommender systems. Although most common uses of recommender systems are noted here, there are many more implementations of these technologies across fields and disciplines.

\section{Social Impact}

Iliadis and Russo $(2016,1)$ introduce critical data studies as the "concept that helps capture the multitude of ways that already-composed data structures inflect and interact with society, its organization and functioning and the resulting impact on individuals' daily lives". 
Hilbert (2013) wrote that technology-initiated shift happened from information to knowledge societies, while elaborating on different kinds of big data: words, locations, nature, behavior, economic activity and others. He considers improvements in medical sphere by using AI algorithms in detecting diseases, but also provides examples from economical sphere in stock market trading including "black box" recommender systems, that can give advices about buying and selling stocks. This is called algorithmic trading. Hilbert concludes that big data holds both promises and dangers for development of societies. The biggest threats seen by Hilbert are potentials for state and corporate control and manipulation and the blind trust in algorithms.

Michael and Miller (2013) note that the new world is turning into "camera", with lots of images and video data. These are captured and then processed by companies, law enforcement agencies and individuals. The issue here is that this kind of new world captures also people that have not given consent to be filmed, while AI technology often comes up with surprising findings and conclusions. The knowledge that person is being constantly supervised and filmed in a company, where he or she works, may outcome with different psychological conditions. On the other hand, the goal is to measure results of work, give recommendations to be included into the work process thus helping companies improve and make progress in their fields. Michael and Miller envision advanced market segmentation, in terms of psychometrics, to get a deep look into personalities of internet users even, to the extent that the main question poses to be, "Who are you?" As the boundaries between public and private blur, Michael and Miller think the volume of data will increase, which gives more space for analysis and even better predictions in various aspects of societies.

\section{Internet Advertising}

The beginning of online advertising seemed as an experiment in 1990s when widespread use of internet began. Since then, online advertising has grown into a \$112.64 billion industry (eMarketer 2018). In early days of internet only banner ads could be seen on different websites. These ads were not personalized or delivered only to those internet users mostly likely to be interested in what they have to offer. Google ads revolutionized ads market by introducing recommender systems. They enable ads to be delivered exactly to those individuals that expressed interest into products or services provided by advertisers. On the other hand, Google ads enable creators of content to embed their ads into websites they use and therefore earn money per click.

When we look at advertising market in Germany between 2000 and 2015 it could be seen that total advertising market decreased from EUR 23.4 bn to 
EUR $21.9 \mathrm{bn}$, while share of spending for online advertising within these sums increased from 1 to 22 percents (IAB Europe 2011). Klapdor (2013) concludes that increase of online advertising both in German and other markers across the globe has been considerable. On the other hand, online share of total advertising varies through the world in 2010. The stats provided by Emarketer (2010) include UK (32\%), Netherlands (21\%), China (19\%), France (18\%), Germany $(17 \%)$, Spain (14\%), USA (11\%) and Italy (5\%). As for population age 14 and above in Germany media consumption increased from 466 mins per day in 2000 to 563 mins per day in 2010. Out of these minutes, internet use increased from only $3 \%$ in 2000 to $14 \%$ in 2010 , while use of all other media decreased in the same period including TV, radio, newspapers, books and magazines (Ridder and Engel 2010). The capabilities of internet in terms of retail sales can be seen in findings about the purchase decisions. Yahoo (2010) presented results of a survey about information used for purchase decision that examined products from different fields including apparel, games, electronics, furniture, foods and DIY. They found that internet was the most important source of information among other ones, such as retail stores, flyers, catalogues, newspapers, friends and magazines.

Adamopoulos, Ghose and Thodri (2018) write that technology has revolutionized how companies deliver ads and communicate with consumers. Ghose and Todri (2016) write that companies monitor digital footprints of consumers, so they can pay per-impression or per-click to the advertising platforms. Thus, these innovations in the world of advertising have been affecting economies on a grand scale. The first disturbances were felt by offline content providers, such as newspapers, that had to cut their circulation volumes and redirect their efforts towards the online sphere. The same happened for TV stations that had to make their websites attractive for online users and change the way they do journalism. New type of journalism was introduced. Multimedia or online journalism has to compete with citizen journalism and different content creators for attention of news consumers in order to get prolonged use, so that they could sell online ads. Of course, online ads business has been affecting other spheres of life, but the most disturbed at first were traditional media. However, the main idea that comes out is that people consume online services more than before, which opens up space for more content creators, but it also makes a difference on the side of advertisers as well, by enabling them to be more effective (Rosenkrans 2009).

New trends in advertising create possibilities for small businesses to get involved into advertising process, thus reaching their target groups with minor amounts of money. Goldfarb (2013) argues that the fundamental economic difference between online and offline advertising is a substantial reduction in the cost of targeting, which boost economic development and empowers small business owners. 


\section{Internet Addiction}

Addict is a person whose normal functioning is endangered because of use directed to the substance or object that is matter of addiction (Young 1998). That means internet or gaming addicts could be overwhelmed playing computer games to the extent that they even avoid eating or performing their physiological needs. Drug addicts may fail to perform in their family roles. They could be aggressive, therefore endangering lives of others and themselves. Gambling addicts may loose their basic assets, such as home they essentially need for daily functioning. To become a media addict there are two main criteria. The first one is extended media use, more than person wants to do that and the other one is this use affects normal daily functioning of that person. Young concludes that internet addiction has a lasting impact on brain processes. She compares internet addiction to addictions of drugs and alcohol.

Statistics show there are 1 to 8 percents of internet addicts in the US, depending from the research standards (Weinstein and Lejoyeux 2010). Durkee et al. (2012) notes results of a study of European countries with internet addiction levels ranging from $1.2 \%$ to $11.8 \%$. Other inquiries from US and Canada report even $20.6 \%$ of internet addicts (Błachnio et al. 2019). On the other side of the globe in South Korea more than $30 \%$ of teenagers are found to be at risk of internet addiction, while in Japan $23.7 \%$ of teenagers were found to be internet addicted (Kawabe et al. 2016). Another study found that Hong Kong teenagers are at great risk to become internet addicts, as Lam (2015) measures internet addiction rate of $24 \%$ among them. However, internet addiction is a growing trend (Chi, Hong, and Chen 2020). The issue of addictiveness is discussed by many researchers that examine impacts of recommender systems. This requires serious research attention (Burr et al. 2018; de Vries 2010; Koene et al. 2015; Taddeo and Floridi 2018; Mančić 2010). Some statistics are even worse. For example, Cheng and $\mathrm{Li}$ (2014) write that 420 million of people were affected by internet addiction in 2014, which is a global average prevalence rate of $6.0 \%$. However, because of increasing internet use, up to date levels of global internet addiction prevalence might be much higher. Montag et al. (2017) writes that between 1996 and 2017, a total of 1,572 papers examines the issue of internet addiction, with rising numbers each year.

\section{Echo Chambers}

Report from the office of President Obama on big data concludes that new technologies can cause social harms on a grand scale, beyond the damages to privacy (White House 2014).

As recommender systems show content consumed by similar people to same group of individuals this makes bubbles of beliefs and attitudes stronger and 
bigger, thus reinforcing polarizations in societies. Such state of matters goes against different views on social issues, public debate and democratic way of functioning, because this could cause unrest, low tolerance, public anger and violent protests (Harambam et al. 2018; Helberger et al. 2016; Koene et al. 2015; Reviglio 2017; Zook et al. 2017). Some researchers call for change in the recommender systems so they can promote diversity of thoughts and attitudes, especially in news segment (Bozdag and van den Hoven 2015). Reviglio (2017) calls for diversified approach in recommender systems, which means it should include different stands from that of the internet user to provide variety and foster democratic processes. The same is request from Harambam et al. (2018) who proposes adding option to configure recommender systems by end users themselves. This would provide novelty, diversity and relevance.

Being in private ownership, without any firm regulatory obligations concerning transparency, big data algorithms are closed circuits. This is identified by D'Ignazio and Bhargava (2015) and it can be a good reason for initiating well prepared digital literacy courses. Authors propose a definition of Big data literacy, because field of internet communication is much more than technical skills one should have to become capable user of new technologies. Thus, big data literacy should be mainly about emancipation, according to D'Ignazio and Bhargava. They also identify various target groups for big data literacy process that include NGOs, those whose work include use of technologies and common citizens.

\section{Discussion}

Based on review of the literature presented in previous sections, we can now elaborate on social impacts of recommender systems.

\section{Internet Advertising}

The typical situation experienced by numerous internet users is that they get recommended ads for exactly the items they intend to buy. They get more options concerning the items they intend to buy, their purchases may be faster, than it would be without recommended ads and finally they may buy more products overall. The fact that internet users get ads based on their interests may be increasing overall retail sales in societies, which is stimulating for economies. Although there are no firm statistics to confirm this notion, some figures indicate that. Emarketer (2019) research shows increase in retail ecommerce sales worldwide from 2014 to 2019 from 6.3 to 12.8 percents (Figure 2.0). The same report indicates constant increase in worldwide retail sales since 2014. Another study shows growth of retail e-commerce sales as share of retail trade in the UK from 2007 to 2019 from 3.4 to 19.2 percents (Lewis 2020). 


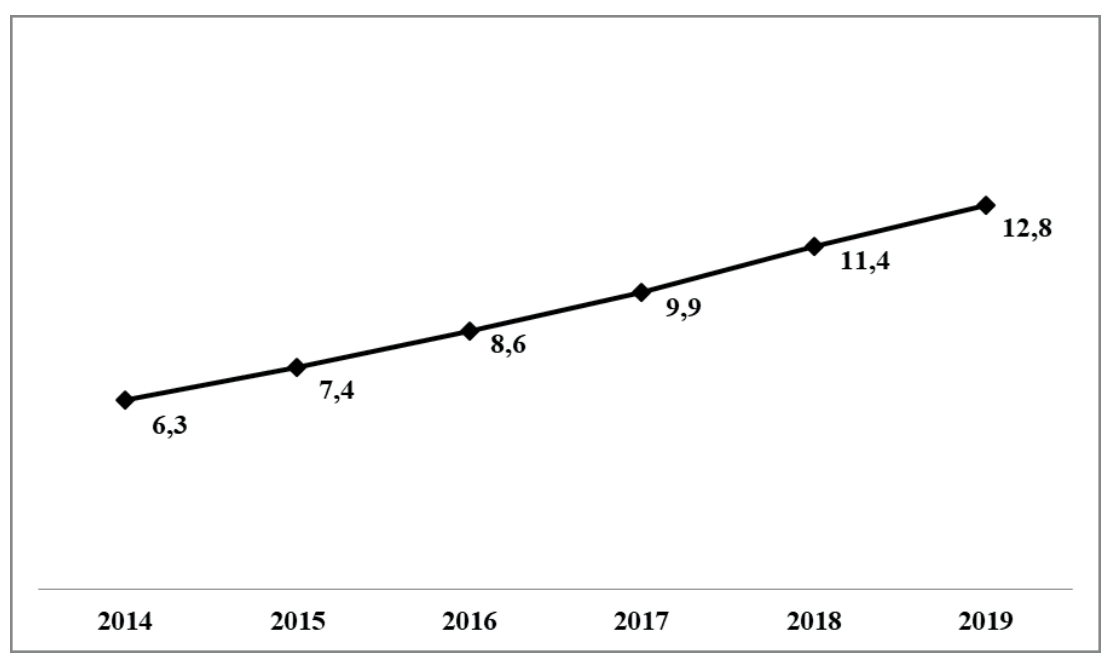

Figure 2.0

Internet sales as a percentage of total retail sales in the world from 2014 to 2019

Additional economic consequence of recommender systems may be democratized advertising. Before online advertising, there were only expensive and ineffective ways to promote products in local communities. Word of mouth was the most effective way to promote products for small companies and individuals that create hand made products. Now, with effectiveness of recommender systems implanted into advertising platforms of today, one can reach potential customers quickly, easily and for small amounts of money. This business model can work, even at a rate of one euro per day, invested by the smallest business owners and startups, and it can still make exquisite results (Liu-Thompkins 2019). Whether the post is sponsored, or there is a specific ad, the right people get the ad, those with the highest possibility to notice it, consider it, interact with the content and then finally make a purchase.

Thus, both potential effects of recommender systems in advertising, such as increases in overall retail sales and democratization of advertising may be supportive for level of employment and current consumption based economic system.

\section{Internet Addiction}

We identified the time management issue as precondition to internet addiction. Almost every recommender system by its definition can increase time people spend online consuming various services. For example if social media user gets friends recommendation for profiles he or she is really interested in, 
this would potentially increase online time of that user, because that person may scroll through the list of recommended friends, send requests to them and ultimately interact with them. Recommended trending content has the same purpose. Video platform such as YouTube offer their users suggested content. These are videos, with the most probability the user would be interested in. This may be tempting, as the users would watch more videos, than they would without this feature. This is also issue of time management. The main question may be if it is better for that person to do something else, than consume online content? There are two directions this kind of overuse could go. One person could do the same kind of activity online, for example communicating indirectly through Viber, as done offline, sharing thoughts and ideas. The question is if direct communication is different in quality when compared to indirect online communication. Is it more rewarding and fulfilling to employ senses of touch, sight and smell, than to enjoy only auditory texting experience through instant messaging app? Or is it better to clean house than to communicate? Substitution of one activity in offline world with the other activity in online sphere may be challenging time management issue of those exposed to recommender systems.

Spending extended time online may lead to internet addiction, because people are tempted to use internet more and more. On the other hand, except noticeable high intensity internet addiction, Bojic, Marie and Brankovic (2013) recognize low intensity internet addiction, which may be at the core of modern mass societies. In other paper, Bojic and Marie (2013) introduce universal methodology for measuring TV, radio, newspapers and internet addiction, that also calculates levels (intensity) of an addiction. They conclude that most of the survey participants show a low level media addiction. Effects of this kind of addiction are not yet examined by scientific inquiries, while possible having major role on social level in respect to democracy, political participation and other aspects of public sphere activities. Low level addictions may have role in individual feelings of happiness and wellbeing, especially if they are joined with other low level addictions, such as shopping, alcohol and similar ones. In other words, if society members spend lots of time online and then go shopping and do other activities which support consumption society, if they are occupied by various stimuli, how much time is it left for thinking and reflection about various personal and common topics including social and political matters? According to proponents of natural law, political justice is applied to citizens who are free, equal and governed by law (Duke 2019). Are our societies free, if they predominantly consist of citizens mildly addicted to their smart phones, brands and other consumption related activities? 


\section{Echo Chambers}

Another issue, that we acknowledged, concerns echo chambers. These are primarily produced by the trending recommender systems, as they reinforce same thoughts and opinions in the digital sphere. As previously noted, recommender systems deliver similar content or the one consumed by similar users. This is a barrier to the social dialogue, because same thoughts and opinions are confirmed all the time. We are witnessing growing polarization in societies across the world, with the main divide being on globalists and nationalists. "High degree of polarization has been connected to unfavorable consequences such as extremism" write Prasetya and Murata $(2020,3)$ and add that other than the polarization of the cascading news, they found that important contributors to polarization were slow opinion update and low tolerance for opinion difference. These trends made a fruitful ground for biased content with sensational headlines and many of these being "fake news." Baumann et al. (2020) proposes an echo chamber research model based on three main assumptions: aggregated social influence, heterogeneous activity and homophily in the interactions. In their research paper Guo, Rohde and Wu (2018) analyze echo chambers created during the 2016 US elections campaigns. They conclude that Twitter communities discussing Trump showed a higher level of heterogeneity, than those about Clinton. As people want to confirm their views, these kind of contents have the greatest probability to be liked or shared further on social media. At the same time, opinions of those that consume this content may radicalize even more, outcoming with hate speech and cutting people out of social networks because of politics, thus creating divided societies of echo chambers, streaming towards differences and further polarizations.

Another potential consequence of recommender systems is using micro targeting for personalized ads in order to impact opinions of individuals and groups, leading towards certain outcomes of elections. Allegedly research results of an inquiry done by Lambiotte and Kosinski (2014) were used in number of political campaigns. The main point was using Facebook likes to determine personality types and then show individual ads with different tone, the ones that will be more likely to be positively accepted by recipients of messages (Isaak and Hanna 2018). In other words, if potential recipient of ad is recognized to be neurotic he or she would receive an "angry ad" packed with negative emotions, while other person, if recognized with high Openness rate, on OCEAN personality scale, would be shown dynamic and positive advertisement. Of course, this could be categorized as recommender system, because it delivers personalized ads, depending from user data, based on psychometric analysis.

If one side in political process uses this kind of technology, it may have competitive advantage. However, if every political party engages in this kind 
of political marketing the conclusion may be that it improves communication as neurotics will get messages of every political option in a way that fits them and with better potential outcomes. In that case, every political party would be equal. The value based conclusion would be that utilizing such psychometric technology would ultimately mean overall improvement in political and other kinds of communication, especially in future, when common people have the knowledge of how recommender systems work and to what kind of technologies they are exposed to.

\section{Conclusions}

Having in mind potential effects of recommender systems and related technologies, including internet advertising related ones, such as increases in overall retail sales and democratized advertising, internet addiction-related ones, such as time management issue and increases in internet addictions and finally democracy-related ones, such as echo chamber issue, and improvement of political communication, some concluding remarks arise.

As discussed in the previous section, although may be challenging to measure and quantify recommender systems in any way, they might be causing increases in overall retail sales. This may be stimulating for consumption society and economies across the globe. If people spend more, then there will be jobs for more people. Although time management issue, internet addictions and social polarization may be consequences of recommender systems, it is clear that current social systems depend on consumption and spending (Fisk 1959). It could be easily seen during the ongoing Covid-19 pandemics what happens to the economy and levels of employment when retail sales decrease in some sectors (Baker et al. 2020).

More research should be directed towards measuring addictions, with special focus on low intensity internet addictions. Despite the fact that internet use is growing in the world, there is no standardized way to measure internet addiction. On the other hand, internet addiction has not been measured in any worldwide study so far. Additionally, special focus of research should be directed towards different addiction levels, meaning intensity of addiction and elements leading towards internet addiction.

Therefore, according to previous arguments, we may formulate a question that might be explored in some future inquiries - if people buy more stuff, does it mean that they are more addicted, or in another words, is there a correlation between volume of retail sales and addictions?

The pandemic intensified digital media habits of citizens, such as work and education from home and e-commerce. The digital media became more than 
ever oversaturated with disinformation, fake news, and various suspicious content. Today, there is a great level of social connectivity, especially through various groups on social media that foster activism. Moreover, in the last two years "Cancel Culture" has been widely accepted as social behavior of unfollowing and boycotting a person, brand, company or organization, due to stressing their different or offending opinion or withholding to support a cause. In such a demanding converged media environment it is necessary to develop and enhance citizen media knowledge and media literacy skills, especially critical thinking, that helps strengthen digital immunity of each individual, as well as society. Digital immunity may help citizens to counter fake news, deal with disinformation and potentially harmful content, to critically evaluate sources, deconstruct media messages and recognize diverse forms of advertising. It also promotes freedom of expression, breaks stereotypes and fosters intercultural dialog.

When looking into the media literacy issue, in their commentary, Couldry and Powell (2014) recommend that highlighting not just the risks of creating and sharing data, but the opportunities would be a way to go. Critical approach to different content could also be significant pillar of media literacy and media education, especially having in mind the outbreak of echo chambers and fake news across the globe (Vosoughi, Roy and Aral 2018). Special attention should be given to the issue of echo chambers, so that citizens get a full understanding of how challenging these kind of recommender systems might be for democracy. While echo chambers are a real challenge and widely-discussed concept, it should be noted that the empirical evidence for their existence in Europe is mixed. Individuals usually consume information by using variety of sources, among traditional and nonlinear media and not relying solely on social media feed or internet searches.

The fact that Facebook was fined by the US regulation authorities for data and privacy breaches, brought spotlight to the issue, leading to increased awareness and discussion about the topic. As there are no immediate value to be acquired by social elites to initiate the topic of recommender systems, this issue stays in the background of the more "important" ones.

Online data will be accessible to companies and political parties in one way or other. Ultimately, the question is not about data access, but rather about data processing and bringing to focus social effects created by businesses, political parties and other organizations taking part. Further scientific inquiries may be directed towards potential points of manipulation and examination into how new technologies function and process data.

Translated by the authors 


\section{Literature}

Abdollahpouri, Himan, Robin Burke and Bamshad Mobasher. 2017. „Recommender Systems as Multistakeholder Environments". In Proceedings of the 25th Conference on User Modeling, Adaptation and Personalization, 347-348. New York, NY, USA: Association for Computing Machinery. https://doi.org/10.1145/3079628.3079657.

Adamopoulos, Panagiotis, Anindya Ghose and Vilma Todri. 2018. „The Impact of User Personality Traits on Word of Mouth: TEXT-MINING Social Media Platforms". Information Systems Research 29 (3): 612-40. https://doi.org/10.1287/isre.2017.0768.

Aggarwal, Charu C. 2016. Recommender Systems: The Textbook. Springer.

Baker, Scott, Nicholas Bloom, Steven Davis and Stephen Terry. 2020. „COVID-Induced Economic Uncertainty“. NBER Working Paper Series 26983: 1-16. https://doi. org/10.3386/w26983.

Balkin, Jack M. 2017. „Free Speech in the Algorithmic SOCIETY: Big Data, Private Governance, and New School Speech Regulation“. SSRN Electronic Journal 615: 1-68. https://doi.org/10.2139/ssrn.3038939.

Baumann, Fabian, Philipp Lorenz-Spreen, Igor M. Sokolov and Michele Starnini. 2020. „Modeling Echo Chambers and Polarization Dynamics in Social Networks“. Physical Review Letters 124 (4): 1-6. https://doi.org/10.1103/physrevlett.124.048301.

Błachnio, Agata, Aneta Przepiórka, Oleg Gorbaniuk, Martina Benvenuti, Adela Magdalena Ciobanu, Emre Senol-Durak, Mithat Durak, et al. 2019. „Cultural Correlates of Internet Addiction“. Cyberpsychology, Behavior, and Social Networking 22 (4): 258-63. https://doi.org/10.1089/cyber.2018.0667.

Bojić, Ljubiša and Jean-Louis Marie. 2013. „Media Addiction by Universal Indicators”. Srpska politička misao 41 (3): 183-97. https://doi.org/10.22182/spm.4132013.9.

Bojić, Ljubiša, Jean-Louis Marie and Srboran Branković. 2013. „Reception and Expression Capabilities of Media Addicts in Serbia”. Kultura polisa 10 (22): 353-368.

Bozdag, Engin and Jeroen van den Hoven. 2015. „Breaking the Filter Bubble: Democracy and Design“. Ethics and Information Technology 17 (4): 249-65. https://doi. org/10.1007/s10676-015-9380-y.

Burr, Christopher, Nello Cristianini and James Ladyman. 2018. „An Analysis of the Interaction between Intelligent Software Agents and Human Users“. Minds and Machines 28 (4): 735-74. https://doi.org/10.1007/s11023-018-9479-0.

Cheng, Cecilia and Angel Yee-lam Li. 2014. „Internet Addiction Prevalence and Quality of (Real) Life: A Meta-Analysis of 31 Nations across Seven World Regions“. Cyberpsychology, Behavior, and Social Networking 17 (12): 755-60. https://doi. org/10.1089/cyber.2014.0317.

Chi, Xinli, Xin Hong and Xiaochen Chen. 2020. „Profiles and Sociodemographic Correlates of Internet Addiction in Early Adolescents in Southern China“. Addictive Behaviors 106: 106-385. https://doi.org/10.1016/j.addbeh.2020.106385.

Couldry, Nick and Alison Powell. 2014. „Big Data from the Bottom Up“. Big Data \& Society 1 (2): 1-5. https://doi.org/10.1177/2053951714539277.

de Vries, Katja. 2010. „Identity, Profiling Algorithms and a World of Ambient Intelligence“. Ethics and Information Technology 12 (1): 71-85. https://doi.org/10.1007/ s10676-009-9215-9. 
Deahl, Erica. 2014. „Better the Data You Know: Developing Youth Data Literacy in Schools and Informal Learning Environments“, PhD diss., Massachusetts Institute of Technology, Cambridge, MA, USA https://dspace.mit.edu/handle/1721.1/89958

D’Ignazio, C. and R. Bhargava. 2015. „Approaches to Building Big data Literacy“. In Bloomberg Data for Good Exchange. New York, NY, USA.

Duke, George. 2019. „Aristotle and Natural Law“. The Review of Politics 82 (1): 1-23. https://doi.org/10.1017/s0034670519000743.

Durkee, Tony, Michael Kaess, Vladimir Carli, Peter Parzer, Camilla Wasserman, Birgitta Floderus, Alan Apter, et al. 2012. „Prevalence of Pathological Internet Use among Adolescents in Europe: Demographic and Social Factors“. Addiction 107 (12): 2210-22. https://doi.org/10.1111/j.1360-0443.2012.03946.x.

Econ. 2017. „The World's Most Valuable Resource Is No Longer Oil, but Data“. Economist. Accessed July 21, 2020. https://www.economist.com/news/leaders/21721656-data-economy-demands-newapproach-antitrust-rules-worlds-most-valuable-resource/

Emarketer. 2010. „EMarketer, Starcom MEDIAVEST GROUP UNVEIL ‘2010 Global MEDIA INTELLIGENCE"“. exchange4media. Accessed August 1, 2020. https:// Www.exchange4media.com/advertising-news/emarketerstarcom-mediavest-group-unveil-2010-global-media-intelligence-39582.html.

Emarketer. 2018. „Digital Display Ad Spending - Reports, Statistics \& Marketing Trends". Insider Intelligence. Accessed August 1, 2020. https:/www.emarketer. com/topics/topic/digital-display-ad-spending.

Emarketer. 2019. „Worldwide Retail Ecommerce Sales: Emarketer's Updated Estimates and FORECAST through 2019“. eMarketer. Accessed August 1, 2020. https:// www.emarketer.com/Report/Worldwide-Retail-Ecommerce-Sales-eMarketers-Updated-Estimates-Forecast-Through-2019/2001716.

Fisk, George. 1959. „Toward a Theory of Leisure-Spending Behavior“. Journal of Marketing 24 (2): 51-57. https://doi.org/10.2307/1248848.

Floridi, Luciano. 2007. „Understanding Epistemic Relevance“. Erkenntnis 69 (1): 6992. https://doi.org/10.1007/s10670-007-9087-5.

Ghose, Anindya and Vilma Todri. 2015. „Towards a Digital Attribution Model: Measuring the Impact of Display Advertising on Online Consumer Behavior". SSRN Electronic Journal 40 (4): 889-910. https://doi.org/10.2139/ssrn.2672090.

Goldfarb, Avi. 2013. „What Is Different about Online Advertising?”. Review of Industrial Organization 44 (2): 115-29. https://doi.org/10.1007/s11151-013-9399-3.

Guo, Lei, Jacob A. Rohde and H. Denis Wu. 2018. ,Who Is Responsible for TWITTER'S Echo Chamber PROBLEM? Evidence from 2016 U.S. ELECTION NETWORKS“. Information, Communication \& Society 23 (2): 234-51. https://doi.org/10.1080/136 9118x.2018.1499793.

Harambam, Jaron, Natali Helberger and Joris van Hoboken. 2018. „Democratizing Algorithmic News Recommenders: How to Materialize Voice in a Technologically Saturated Media Ecosystem“. Philosophical Transactions of the Royal Society A: Mathematical, Physical and Engineering Sciences 376, no. 2133: 1-21. https://doi. org/10.1098/rsta.2018.0088. 
Helberger, Natali, Kari Karppinen and Lucia D’Acunto. 2016. „Exposure Diversity as a Design Principle for Recommender Systems“. Information, Communication \& Society 21 (2): 191-207. https://doi.org/10.1080/1369118x.2016.1271900.

Helbing, Dirk. 2015. Thinking Ahead: Essays on Big Data, Digital Revolution, and Participatory Market Society. Berlin: Springer.

Hern, Alex and David Pegg. 2018. „Facebook Fined for Data Breaches in Cambridge Analytica Scandal“. The Guardian. Accessed July 10, 2018. https://www.theguardian.com/technology/2018/jul/11/facebook-fined-for-data-breaches-in-cambridge-analytica-scandal.

Hilbert, Martin. 2013. „Big Data for Development: From Information - to Knowledge Societies“. SSRN Electronic Journal 1-39. https://doi.org/10.2139/ssrn.2205145.

Howard, Philip N., Bharath Ganesh, Dimitra Liotsiou, John Kelly and Camille François. 2019. „The IRA, Social Media and Political Polarization in the United States, 2012-2018“.DigitalCommons@University of Nebraska-Lincoln. Accessed August 1, 2021. https://digitalcommons.unl.edu/senatedocs/1/.

IAB Europe. 2011. „AdEx 2010 European online advertising expenditure“. IAB Europe. Accessed July 27, 2020. https://iabeurope.eu/uncategorized/iab-europe-reports-european-advertising-spend-2008-2013/.

Iliadis, Andrew and Federica Russo. 2016. „Critical Data Studies: An Introduction“. Big Data \& Society 3 (2): 1-7. https://doi.org/10.1177/2053951716674238.

Internetworldstats. 2020. ,Internet Growth STATISTICS 1995 to 2021 - the Global VILLAGE ONLINE“. Internet World Stats. Accessed August 1, 2021. https://www. internetworldstats.com/emarketing.htm.

Isaak, Jim and Mina J. Hanna. 2018. ,User Data Privacy: Facebook, Cambridge Analytica, and Privacy Protection“. Computer 51 (8): 56-59. https://doi.org/10.1109/ mc.2018.3191268.

Kawabe, Kentaro, Fumie Horiuchi, Marina Ochi, Yasunori Oka and Shu-ichi Ueno. 2016. „Internet Addiction: Prevalence and Relation with Mental States in Adolescents“. Psychiatry and Clinical Neurosciences 70 (9): 405-12. https://doi. org/10.1111/pcn.12402.

Kitchin, Rob and Gavin McArdle. 2016. „What Makes Big Data, Big Data? Exploring the Ontological Characteristics of 26 Datasets“. Big Data \& Society 3 (1): 1-10. https://doi.org/10.1177/2053951716631130.

Kitchin, Rob. 2013. „Big Data and Human Geography“. Dialogues in Human Geography 3 (3): 262-67. https://doi.org/10.1177/2043820613513388.

Klapdor, Sebastian. 2013. Effectiveness of Online Marketing Campaigns an Investigation into Online Multichannel and Search Engine Advertising. Wiesbaden: Springer.

Koene, Ansgar, Elvira Perez, Christopher James Carter, Ramona Statache, Svenja Adolphs, Claire O’Malley, Tom Rodden and Derek McAuley. 2015. „Ethics of Personalized Information Filtering“. Internet Science 123-132. https://doi.org/10.1007/9783-319-18609-2_10.

Konow, Roberto, Wayman Tan, Luis Loyola, Javier Pereira and Nelson Baloian. 2010. „Recommender System for Contextual Advertising in Iptv Scenarios“. The 2010 14th International Conference on Computer Supported Cooperative Work in Design, Shanghai, China, 617-622. https://doi.org/10.1109/cscwd.2010.5471900. 
Kosinski, M., D. Stillwell and T. Graepel. 2013. „Private Traits and Attributes Are Predictable from Digital Records of Human Behavior". Proceedings of the National Academy of Sciences 110 (15): 5802-5805. https://doi.org/10.1073/pnas.1218772110.

Lam, Lawrence T. 2015. „Parental Mental Health and Internet Addiction in Adolescents“. Addictive Behaviors 42: 20-23. https://doi.org/10.1016/j.addbeh.2014.10.033.

Lambiotte, Renaud and Michal Kosinski. 2014. „Tracking the Digital Footprints of Personality“. Proceedings of the IEEE 102 (12): 1934-39. https://doi.org/10.1109/ jproc.2014.2359054.

Laney, D. 2020. „3D data management: Controlling data volume, velocity and variety“. Meta Group. Accessed July 27, 2020. http://blogs.gartner.com/doug-laney/ files/2012/01/ad949-3D-Data-Management-Controlling-Data-VolumeVelocity-and-Variety.pdf.

Lewis, Rhys. 2020. „Internet Sales as a Percentage of Total Retail Sales (Ratio) (\%)“. Office for National Statistics. Accessed July 22, 2020. https:/www.ons.gov.uk/businessindustryandtrade/retailindustry/timeseries/j4mc/drsi.

Li, Yung-Ming and Ya-Lin Shiu. 2012. „A Diffusion Mechanism for Social Advertising over Microblogs“. Decision Support Systems 54 (1): 9-22. https://doi.org/10.1016/j. dss.2012.02.012.

Liu-Thompkins, Yuping. 2019. „A Decade of Online Advertising Research: What We Learned and What We Need to Know“. Journal of Advertising 48 (1): 1-13. https:// doi.org/10.1080/00913367.2018.1556138.

Mai, Jens-Erik. 2016. „Big Data Privacy: The Datafication of Personal Information“. The Information Society 32 (3): 192-199. https://doi.org/10.1080/01972243.2016. 1153010 .

Mancic, Zeljko. 2010. „Cyberpiracy and Morality: Some Utilitarian and Deontological Challenges“. Filozofija i drustvo 21 (3): 103-117. https://doi.org/10.2298/ fid $1003103 \mathrm{~m}$.

Michael, Katina and Keith W. Miller. 2013. „Big Data: New Opportunities and New Challenges“. Computer 46 (6): 22-24. https://doi.org/10.1109/mc.2013.196.

Milano, Silvia, Mariarosaria Taddeo and Luciano Floridi. 2020. „Recommender Systems and Their Ethical Challenges“. AI \& Society 35 (4): 957-967. https://doi. org/10.1007/s00146-020-00950-y.

Montag, Christian, Éilish Duke and Martin Reuter. 2017. „A Short Summary of Neuroscientific Findings on Internet Addiction“. In Internet Addiction. Studies in Neuroscience, Psychology and Behavioral Economics., edited by Christian Montag and Martin Reuter, 209-218. Cham: Springer. https://doi.org/10.1007/978-3-319-46276-9_12.

Patel, Archana and Sarika Jain. 2019. „Present and Future of Semantic Web Technologies: A Research Statement". International Journal of Computers and Applications 43 (5): 413-422. https://doi.org/10.1080/1206212x.2019.1570666.

Prasetya, Hafizh A. and Tsuyoshi Murata. 2020. „A Model of Opinion and Propagation Structure Polarization in Social Media“. Computational Social Networks 7 (1): 1-10. https://doi.org/10.1186/s40649-019-0076-z.

Rashid, Al Mamunur, Istvan Albert, Dan Cosley, Shyong K. Lam, Sean M. McNee, Joseph A. Konstan and John Riedl. 2002. „Getting to Know You“. Proceedings of the 7th international conference on Intelligent user interfaces - IUI '02 127-134. https:// doi.org/10.1145/502716.502737. 
Resnick, Paul and Hal R. Varian. 1997. „Recommender Systems“. Communications of the ACM 40 (3): 56-58. https://doi.org/10.1145/245108.245121.

Reviglio, Urbano. 2017. „Serendipity by Design? How to Turn from Diversity Exposure to Diversity Experience to Face Filter Bubbles in Social Media“. Internet Science 281-300. https://doi.org/10.1007/978-3-319-70284-1_22.

Ricci, Francesco, Lior Rokach and Bracha Shapira. 2011. „Introduction to Recommender SYSTEMS HANDBOOK“. Recommender Systems Handbook 1-35. https://doi. org/10.1007/978-0-387-85820-3_1.

Rosenkrans, Ginger. 2009. „The Creativeness and Effectiveness of Online Interactive Rich Media Advertising“. Journal of Interactive Advertising 9 (2): 18-31. https:// doi.org/10.1080/15252019.2009.10722152.

Schuilenburg, Marc and Rik Peeters. 2021. The Algorithmic Society: Technology, Power, and Knowledge. London: Routledge.

Statista. 2020. „Biggest Companies in the World by Market Cap 2020“. Statista. Accessed May 31, 2020. https://www.statista.com/statistics/263264/top-companies-inthe-world-by-market-value/.

Sutikno, Tole, Lina Handayani, Deris Stiawan, Munawar Agus Riyadi and Imam Much Ibnu Subroto. 2016. ,WhatsApp, Viber and Telegram Which Is Best for Instant Messaging?". International Journal of Electrical and Computer Engineering (IJECE) 6 (3): 909-914. https://doi.org/10.11591/ijece.v6i3.pp909-914.

Taddeo, Mariarosaria and Luciano Floridi. 2018. „How Ai Can Be a Force for Good“. Science 361 (6404): 751-752. https://doi.org/10.1126/science.aat5991.

Vosoughi, Soroush, Deb Roy and Sinan Aral. 2018. „The Spread of True and False News Online“. Science 359 (6380): 1146-1151. https://doi.org/10.1126/science.aap9559.

Wang, Yilun and Michal Kosinski. 2018. „Deep Neural Networks Are More Accurate than Humans at Detecting Sexual Orientation from Facial Images“. Journal of Personality and Social Psychology 114 (2): 246-257. https://doi.org/10.1037/ pspa0000098.

Weinstein, Aviv and Michel Lejoyeux. 2010. „Internet Addiction or Excessive Internet Use“. The American Journal of Drug and Alcohol Abuse 36 (5): 277-83. https://doi. org/10.3109/00952990.2010.491880.

White House. 2014. Big data: Seizing opportunities, preserving values. Executive Office of the President. Washington, DC.

Yahoo. 2010. „Das Web als zentrales Element für die Kaufentscheidung im Einzelhandel“" Yahoo Research. Accessed July 21, 2020. https://docplayer.org/8422159-Das-web-als-zentrales-element-fuer-die-kaufentscheidung-im-einzelhandel-yahoo-insights-juni-2010.html.

Young, Kimberly S. 1998. „Internet Addiction: The Emergence of a New Clinical Disorder“. CyberPsychology \& Behavior 1 (3): 237-244. https://doi.org/10.1089/ cpb.1998.1.237.

Zook, Matthew, Solon Barocas, Danah Boyd, Kate Crawford, Emily Keller, Seeta Peña Gangadharan, Alyssa Goodman, et al. 2017. „Ten Simple Rules for Responsible Big Data Research“. PLOS Computational Biology 13 (3): 1-10. https://doi.org/10.1371/ journal.pcbi.1005399.

Zwitter, Andrej. 2014. „Big Data Ethics“. Big Data \& Society 1 (2): 1-6. https://doi. org/10.1177/2053951714559253. 
Ljubiša Bojić

Institut za filozofiju i društvenu teoriju,

Univerzitet u Beogradu

Maja Zarić

Savetnik u Ministarstvu kulture Republike Srbije

Simona Žikić

Fakultet za medije i komunikacije, Unverzitet Singidunum

Institut za filozofiju i društvenu teoriju,

Univerzitet u Beogradu

Zabrinjavajući uticaj veštačke inteligencije i velikih podataka kroz prizmu sistema za preporučivanje

Prelazak iz društvenog u semantički veb doveo nas je u eru algoritmičkog društva, u kojoj su pitanja privatnosti, velikih podataka i veštačke inteligencije u fokusu. Iako neutralni po svojoj prirodi, moć algoritama koji operišu sa velikim podacima postaje značajno društveno pitanje, što je za posledicu imalo kažnjavanje kompanije Fejsbuk u SAD. Ovo je inicirano kršenjima privatnosti podataka vezanim za tehnologiju sistema za preporučivanje, koja može da pruži personalizovane sadržaje korisnicima interneta. Rad ima za cilj da objasni sisteme za preporučivanje, kao i njihove moguće društvene posledice kao što su opšte povećanje prodaje, demokratizacija reklamiranja, povećanje internet zavisnosti, povećanje društvene polarizacije (echo chamber) i poboljšanje komunikacije između političkih organizacija i građana. Više istraživanja treba da se posveti zavisnostima manjeg intenziteta. Takođe treba dublje istražiti na koji način sistemi za preporučivanje utiču na demokratiju.

Ključne reči: Sistemi za preporučivanje, veštačka inteligencija, veliki podaci, internet zavisnost, echo chamber

Influence inquiétante de l'intelligence artificielle et de mégadonnées à travers le prisme du système de recommandation

Le passage du web social au web sémantique nous a conduit dans la période de la société algorithmique où on se concentre sur les questions des données personnelles, des mégadonnées et de l'intelligence artificielle. Bien que les algorithmes soient neutres par leur nature, le pouvoir de ceux qui opèrent avec les mégadonnées devient une question sociale importante ayant eu pour conséquence la condamnation de la compagnie Facebook aux États-Unis. Cela a été initié par les violations de données personnelles liées à la technologie du système de recommandation pouvant fournir des contenus personnalisés aux 
internautes. L'objectif du travail est d'expliquer les systèmes de recommandation ainsi que leurs conséquences sociales possibles telles que l'augmentation générale de vente, démocratisation de la publicité, augmentation de cyberdépendance, expansion de la polarisation sociale (chambre d'écho) et amélioration de la communication entre les organisations politiques et les citoyens. Il faut consacrer plus d'études aux dépendances de moindre intensité. Il faut aussi examiner encore plus la manière par laquelle les systèmes de recommandation influencent la démocratie.

Mots-clés : systèmes de recommandation, intelligence artificielle, mégadonnées, cyberdépendance, chambre d'écho

Primljeno / Received: 4.03.2021.

Prihvaćeno / Accepted: 31.07.2021. 